\title{
ANALISIS KINERJA HEAT EXCHANGER TYPE SHELL AND TUBE BERBAHAN TEMBAGA ALIRAN SEARAH DAN ALIRAN BERLAWANAN TANPA RADIATOR
}

\author{
FANNI FATTAH ${ }^{1}$ AHMAD ISKANDAR ${ }^{2}$ \& $^{\text {Rudiyo }^{3}}$ \\ 1,2,3 Program Studi Teknik Mesin, Fakultas Teknik, Universitas Muhammadiyah Tangerang \\ Jl. Perintis Kemerdekaan I/33 Cikokol-Tangerang \\ E-mail:vanfattah@gmail.com
}

\begin{abstract}
ABSTRAK
Alat penukar kalor atau heat exchanger adalah suatu alat yang memungkinkan perindahan panas dan bisa berfungsi sebagai pemanas maupun sebagai pendingin. Penukar panas dirancang sebisa mungkin agar perpindahan panas antar fluida dapat berlangsung secara efisien. Pertukaran panas terjadi karena adanya kontak, baik antara fluida yang bercampur maupun fluida yang terpisahkan oleh sekat. Perubahan laju aliran pada heat exchanger tertunya berpengaruh terhadap pendinginan.Tujuan penelitian ini adalah (1) Mengetahui dan memahami sistem kerja heat exchanger type shell and tube. (2) Mampu menganalisa dan menyimpulkan hasil penelitian laju aliran pada shell and tube dengan tabel maupun grafik. Perpindahan kalor tersebut selisih temperatur tube (masuk dan keluar) untuk fluida panas tanpa pendingin dan hasil pada fluida panas dengan fluida dingin yang akan berhubungan dengan perbedaan rata-rata fluida panas dan dingin dan nilai afktifitas alat penukar kalor. Sebagai variebel laju aliran yang akan dirubah untuk mencari perbandingan. Setelah dilakukan perbaikan dan perancangan ulang Alat uji heat exchanger generasi ke-2 sudah lebih baik dibandingkan dengan alat uji heat exchanger generasi pertama, dilihat dari Efektifitas alat heat exchanger ditemukan adanya peningkatan keefektifan dari $12 \%$ menjadi 91,94\% kenaikan Efektifitas heat exchanger dikarenakan sudah tidak adanya kebocora pada sekat shell and tube (bufler).
\end{abstract}

Kata kunci: Konversi Energi; Perancangan; Manufaktur; Pengolahan Material; Teknik Mesin.

\begin{abstract}
A heat exchanger or heat exchanger is a device that allows heat transfer and can function as a heater or as a coolant. The heat exchanger is designed as much as possible so that heat transfer between fluids can take place efficiently. Heat exchange occurs due to contact between mixed fluids and fluids separated by a bulkhead. The change in flow rate of the heat exchanger has an effect on cooling. The objectives of this study are (1) Knowing and understanding the shell and tube type heat exchanger working system. (2) Able to analyze and conclude the results of the flow rate research on shell and tube with tables and graphs. The heat transfer is the difference in tube temperature (in and out) for hot fluids without cooling and the results for hot and cold fluids which will be related to the average difference between hot and cold fluids and the value of heat exchanger affinity. As the flow rate variable will be changed to find a comparison. After repairing and redesigning the second generation heat exchanger test equipment, it was better than the first generation heat exchanger test equipment, seen from the effectiveness of the heat exchanger, it was found that there was an increase in effectiveness from $12 \%$ to $91.94 \%$. absence of leaks in the shell and tube bulkhead (bufler).
\end{abstract}

Keywords: Energy Conversion, Design, Manufacture, Materials Processing, Mechanical Engineering.

\section{PENDAHULUAN}

Energi berasal dari bahasa Yunani yaitu energia yang berarti kegiatan/aktivitas. Menurut Michael J. Moran, energi merupakan properti fisika dari suatu objek dimana dapat berubah bentuk akan tetapi tidak dapat diciptakan atau dimusnahkan, energi merupakan konsep dasar dari Termodinamika yang menjadi aspek yang penting dari analisis teknis. Ada banyak jenis bentuk energi dalam kehidupan sehari-hari. Dari sekian banyak jenis energi kalor merupakan salah satunya.

Kalor adalah suatu bentuk energi yang berpindah dari suatu benda bersuhu tinggi ke benda bersuhu rendah dengan kontak langsung. Menurut Antoine Laurent Lavoiser (1743 - 1794) Kalor berasal dari kata caloric, Satuan kalor ditetapkan 
dengan nama kalori (kal). Energi kalor dapat berubah menjadi energi mekanik (joule) atau sebaliknya seorang ilmuwan berbangsaan Inggris bernama James Prescott Joule (1818 - 1889), menemukan Hubungan ini dengan perbandingan 1 $\mathrm{kkal}=4,184 \times 10^{3}$ joule.

Dari sekian banyak jenis heat exchanger yang telah dikenal, maka penulis tertarik untuk melakukan penelitian heat exchanger dengan jenis TEMA (Turbular Exchanger Manufacturers Association) yaitu jenis asosiasi alat penukar panas jenis shell and tube. Kontruksi ini adalah satu selongsong dengan dua pipa atau lebih yang di lengkapi dengan sekat yang biasa di sebut baffle.

Aliran pada heat exchanger tentunya terjadi perubahan. Perubahan terjadi karena terjadi penurunan laju aliran akibat sehingga terjadi penurunan tekanan. Pada luas penampang yang sama laju aliran yang berubah maka akan berpengaruh pada kecepatan aliran. Bentuk aliran dapat berupa laminar, turbulen maupun transisi antara laminar dan turbulen. Perubahan laju aliran pada heat exchanger tertunya berpengaruh terhadap pendinginan. Pengaruh perubahan laju aliran tersebut tentunya dapat dihitung dengan rumus. Pada tahap penelitian generasi pertama ditemukan

beberapa kekurangan dari data sebelumnya. Berdasarkan latar belakang diatas maka dari itu penulis mengambil judul "Analisa Kinerja Heat Exchanger Shell and Tube Aliran Searah dan Berlawanan".

\section{METODOLOGI PENELITIAN}

Pada penelitian ini penulis menggunakan beberapa metode diantaranya: Metode Observasi, Studi Literatur dan eksperimen, dimana metode eksperimen merupakan metode penelitian yang digunakan untuk mencari pengaruh perlakuan tertentu terhadap yang lain dalam kondisi yang terkendalikan (Sugiono: 2010). Dalam metode penelitian ini berupa perancangan serta pungujian Heat Exchanger Shell and Tube. Adapun penujian pada aliran searah dan berlawanan untuk mengetahui Kinerja alat dilihat dari fenomena aliran serta efktifitas.

\subsection{Skema Aliran}

Pada peracangan heat exchanger tentunya diketahui skema aliran yang akan dibuat. Skema aliran meliputi pendinginan pada menuju shell and tube dan penempatan komponen pendukung pada heat exchanger. Berikut skema aliran heat exchanger pada Gambar 1.

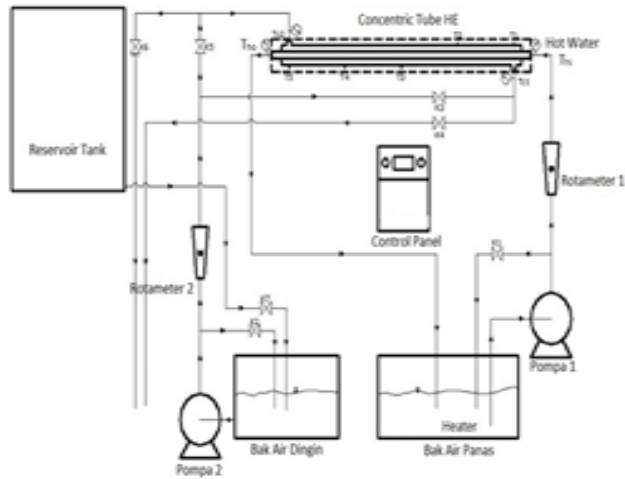

Gambar 1. Skema laju aliran Heat Exchanger (Sumber: Ma’a (2013))

\subsection{Aliran Heat Exchanger counter flow / Berlawanan}

Pertukaran panas dengan aliran berlawanan arah (counter current / flow) yaitu bila kedua fluida mengalir dengan arah yang saling berlawanan dan keluar pada sisi yang berlawanan.

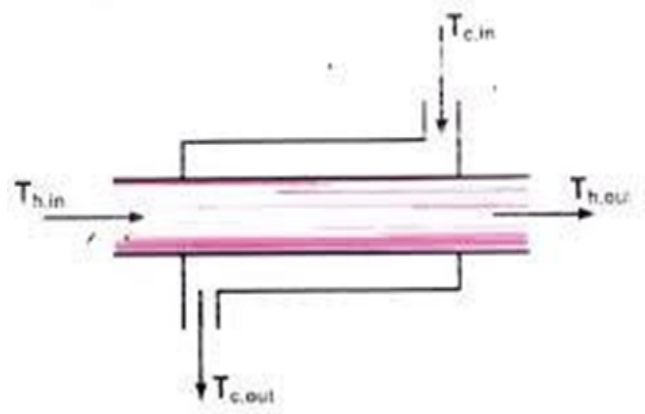

\section{Gambar 2. Aliran Counter flow/berlawanan}

(Sumber http://journal.unj.ac.id)

\subsection{Aliran Heat Exchanger Searah}

Penentuan desain aliran fluida di dalam sebuah heat exchanger tergantung dari kebutuhan tingkat keefektifan perpindahan panas yang diinginkan, penurunan tekanan yang diijinkan, kecepatan aliran fluida minimum dan maksimum yang diperbolehkan, bentuk aliran fluida, desain bentuk heat exchanger, tegangan termal yang diijinkan, perubahan temperatur yang dibutuhkan, desain sistem perpipaan, serta berbagai pertimbangan yang lain. Untuk lebih jelasnya perhatikan Gambar 3 di bawah ini. 


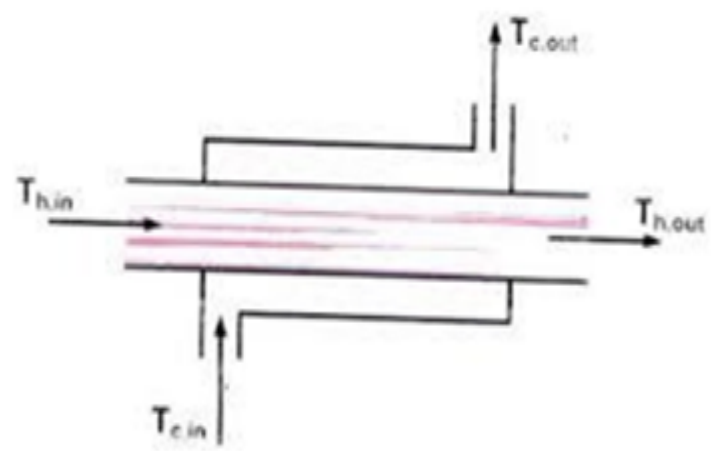

Gambar 3. Aliran Paralel Flow Heat Exchanger

(Sumber http://journal.unj.ac.id)

\subsection{Diagram Alir}

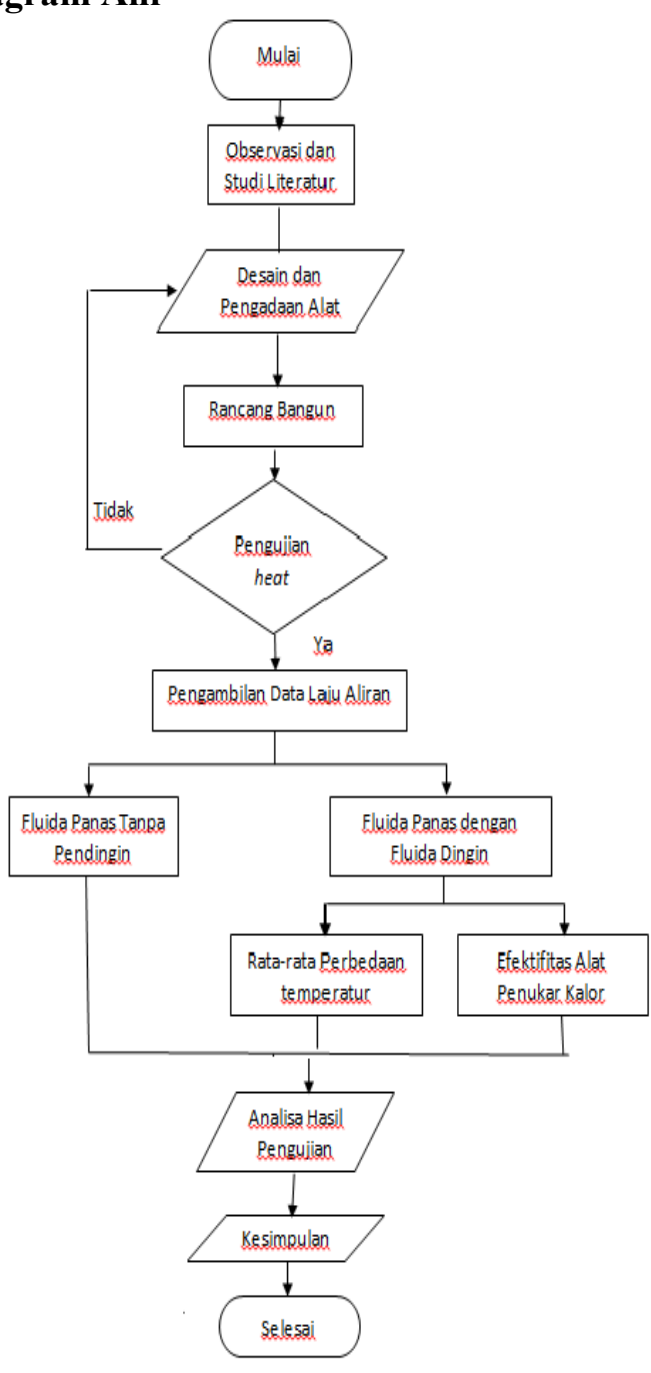

Gambar 4. Diagram Alir.

\subsection{Design Heat Exchanger}

Desain Heat Exchanger ini disesuaikan dengan permintaan dalam variable pengujian atau penelitian. Tentunya komponen dan sistem pemipaan akan ditambah. Design dapat dilihat pada Gambar 5.

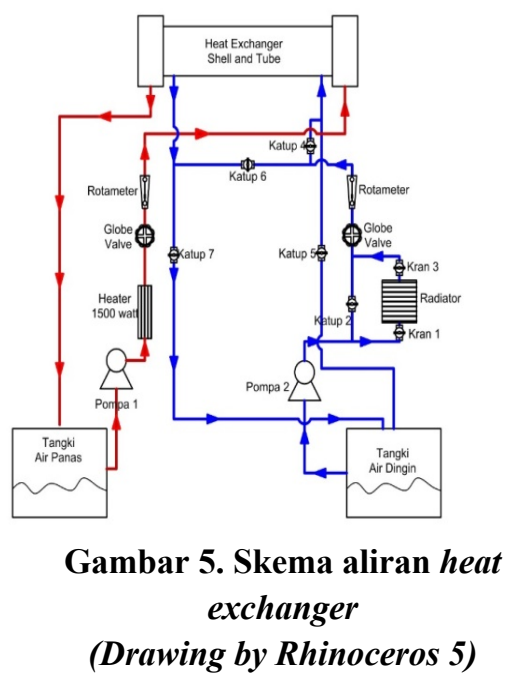

Dari gambar 5. menunjukan sistem pemipaan dengan sistem katup. Ada tujuh katup pada heat excharger yang sesuai permintaan pada pengambilan data.Permintaan tersebut antara lain :

a. Aliran fluida searah tanpa radiator.

b. Aliran fluida berlawan arah tanpa radiator.

c. Aliran fuida searah dengan radiator.

d. Aliran fluida berlawan arah dengan radiator.

\subsection{Improvement Komponen Pada Alat Uji Heat Exchanger}

Pada penelitian ini penulis melakukan perbaikan terhadap beberapa komponen yang sudah rusak dan mengalami kebocoran pada bagian alat uji heat exchanger gererasi pertaman, setelah melakukan analisa dan diskusi menegenai banyakanya kerusakan pada alat uji heat exchanger gererasi pertaman, penulisa melakuakan beberapa perbaikan dan penggantian pada beberapa komponen yang sudah tidak berfungi ataupun komponen yang masih berfungsi namun tidak berfungsi secara maksimal. Adapun modifikasi yang dilakukan data dilihat di Tabel 1 . 
Tabel 1. improvement pada Design Alat Heat Exchanger

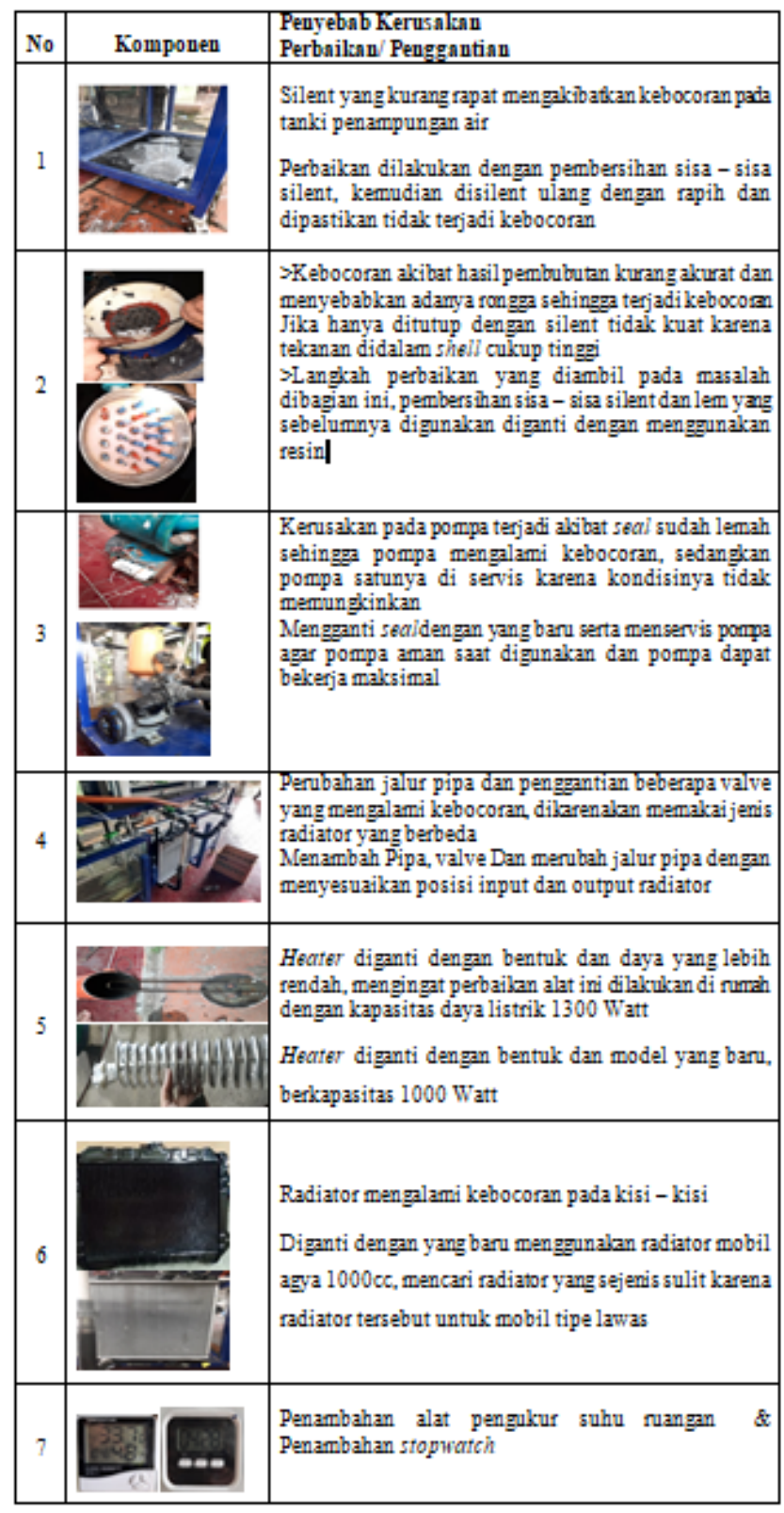

\section{HASIL DAN PEMBAHASAN}

Heat exchanger atau alat penukar / pemindah panas adalah alat-alat yang digunakan untuk mengubah temperatur fluida atau mengubah fasa fluida dengan cara mempertukarkan panasnya dengan fluida lain.

Pada sebuah penukar panas, kemampuan mempertukarkan panas sangat ditentukan oleh jenis aliran fluida dan fluida yang melewati penukar panas tersebut.
Penelitian ini bertujuan untuk mengetahui dan menyempurnakan alat penguji heat exchanger yang sudah pernah dilakukan sebelumnya. Pada penelitian pertama dilakukan selama 60 menit namun dimenit ke 30 ditemukan kebocoran (trouble) pada dinding shell atau sekat buffer, oleh sebab itu peneliti mencoba melakukan optimasi pada mesin heat exchanger generasi pertam. Volume air panas yang digunakan sebanyak 25 liter dan volume air dingin 120 liter. Dalam pengambilan data ini waktu yang di gunakan adalah selama 60 menit dengan interval waktu 5 menit sehingga mendapatkan data sebanyak 13 kali pengambilan data, maka dapat di peroleh data pada Tabel 1.

Berdasarkan data hasil penelitian sesuai dengan gambar 7. Maka dapat dijelaskan bahwa kinerja heat exchanger type shell and tube generasi ke dua mengunakan fluida air tanpa pendingin atau radiator tidak ditemukan kebocoran, dimenit ke 10 mengalami penurunan suhu pada temperature air panas menjadi $41.7^{\circ} \mathrm{C}$, di menit ke 30 diperoleh data uji penelitian mengalami penurunan sebesar $39.0{ }^{\circ} \mathrm{C}$ di menit ke 60 mengalami kenaikan sebesar $39,7^{\circ} \mathrm{C}$.

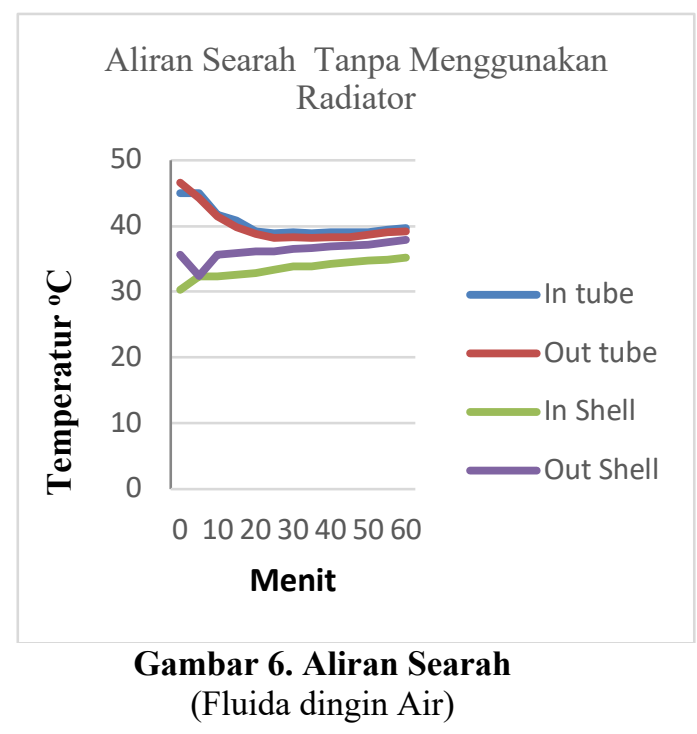




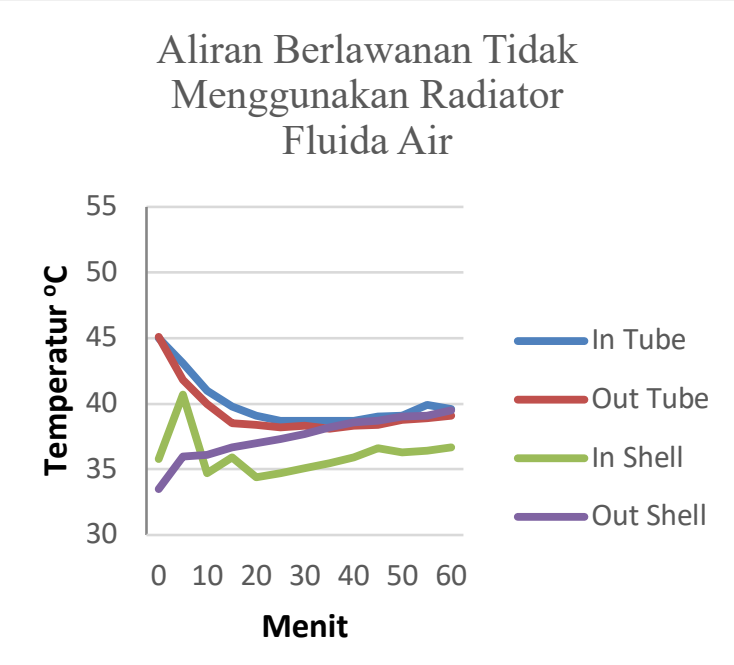

Gambar 7. Aliran Berlawanan (Fluida dingin Air).

Berdasarkan pada Gambar 7 pada temperatur fluida air dingin pada menit ke 10 mengalami kenaikan perpindahan panas sebesar 4.559 Watt sehingga mengakibatkan naiknya suhu fluida air dingin menjadi $35.7^{\circ} \mathrm{C}$.

\subsection{Perhitungan Data Heat Exchanger Type Shell and Tube.}

Setelah didapatkan data - data pengujian pada tabel diatas untuk menghitung nilai massa laju aliran pada shell and tube, nilai perpindahan panas pada shell and tube, (Log Mean Temperature Difference) LMTD, luas permukaan pipa, menghitung koefisien perpindahan kalor menyeluruh, menghitung luas penampang shell and tube, menghitung kecepatan aliran pada shell and tube, menghitung bilangan reynold, menghitung efisiensi heat exchanger. Hasil perhitungan heat exchanger Tabel 2.

Setelah melihat Tabel 2, Penulis menyimpulkan bahwa rata - rata perbandingan temperatur pada aliran searah air $6,99^{\circ} \mathrm{C}$, aliran berlawanan air sebesar $5^{\circ} \mathrm{C}$, aliran searah dengan radiator sebesar $2,3^{\circ} \mathrm{C}$ aliran berlawanan dengan radiator sebesar $3,3^{\circ} \mathrm{C}$, Massa laju aliran pada shell $0,33 \mathrm{~m} / \mathrm{s}$, dan untuk Koefisien perpindahan panas pada setiap sisi itu berbeda dikarenakan seriap fenomena pelepasan dan peneriman kalor pada setiap sisi itu berbeda-beda.

Untuk mengetahui perbandingan perubahan temperatur aliran searah dan aliran berlawanan tanpa menggunakan radiator atau pendingin dengan aliran searah dan berelawanan menggunakan radiator atau pendingin yang mana data di lihat pada Gambar 8.
Tabel 2. Hasil perhitungan searah dan berlawanan fluida air dengan Radiator

\begin{tabular}{|c|c|c|c|c|c|c|}
\hline No & Parameter & $\begin{array}{l}\text { Aliran } \\
\text { Searah } \\
\text { Air }\end{array}$ & $\begin{array}{l}\text { Aliran } \\
\text { Berlawanan } \\
\text { Air }\end{array}$ & $\begin{array}{l}\text { Aliran } \\
\text { Searah } \\
\text { Deugau } \\
\text { Radiator }\end{array}$ & \begin{tabular}{|c|} 
Aliran \\
Berlawanan \\
Dengan \\
Radiator \\
\end{tabular} & Satuan \\
\hline 1. & $\begin{array}{c}\text { Massa laju } \\
\text { aliran pada } \\
\text { shell }\end{array}$ & 0,33 & 0,33 & 0,33 & 0,33 & $\mathrm{~kg} / \mathrm{s}$ \\
\hline 2. & $\begin{array}{c}\text { Massa laju } \\
\text { aliran pada } \\
\text { tibe }\end{array}$ & 0,198 & 0,198 & 0,198 & 0,198 & $\mathrm{~kg} / \mathrm{s}$ \\
\hline 3. & $\begin{array}{l}\text { Selisih rata - } \\
\text { rata } \\
\text { Temperatur } \\
\text { LMTD }\end{array}$ & 6.99 & 5 & 2,3 & 3,3 & ${ }^{\circ} \mathrm{C}$ \\
\hline 4. & $\begin{array}{l}\text { Kecepatan } \\
\text { aliran pada } \\
\text { tube }\end{array}$ & 0,66 & 0,66 & 0,66 & 0,66 & $\mathrm{~m} / \mathrm{s}$ \\
\hline 5. & $\begin{array}{c}\text { Kecepatan } \\
\text { aliran pada } \\
\text { shell }\end{array}$ & 0,037 & 0,036 & 0,037 & 0,036 & $\mathrm{~m} / \mathrm{s}$ \\
\hline 6. & $\begin{array}{c}\text { Bilangan } \\
\text { Reynold } \\
\text { Tube }\end{array}$ & 3969,1 & 3974 & 3962 & 4071 & \\
\hline 7. & $\begin{array}{c}\text { Bilangan } \\
\text { Reynold } \\
\text { Shell }\end{array}$ & 6123 & 4191 & 6793 & 5881 & \\
\hline 8. & $\begin{array}{c}\text { Koefisien } \\
\text { perpindahan } \\
\text { panas sisi tube }\end{array}$ & 4966 & 4961 & 4959 & 5016 & $W / m^{2}{ }^{\circ} \mathrm{C}$ \\
\hline 9. & $\begin{array}{c}\text { Koefisien } \\
\text { perpindahan } \\
\text { panas sisi shell }\end{array}$ & 4646 & 3828 & 4678 & 4616,5 & $W / m^{2}{ }^{\circ} \mathrm{C}$ \\
\hline 10. & $\begin{array}{l}\text { Perpindahan } \\
\text { panas } \\
\text { menveluruh }\end{array}$ & 475,4 & 466.07 & 4876 & 4107 & $W / m^{2}{ }^{\circ} \mathrm{C}$ \\
\hline
\end{tabular}

Aliran Berlawanan ( Fluida Air ) Menggunakan Radiator Dan Tanpa Radiator

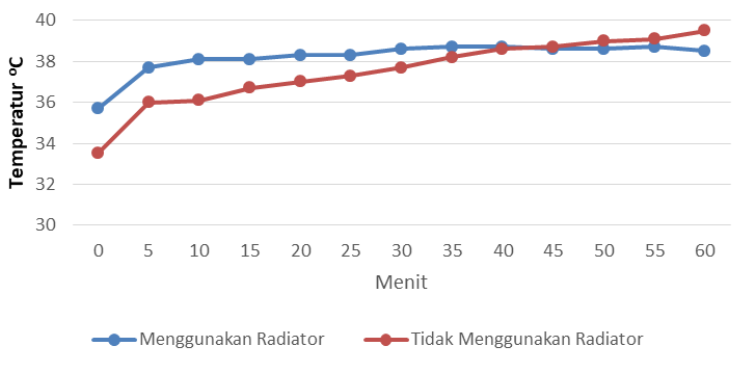

Gambar 8. Aliran Berlawanan menggunakan Radiator dan Nonradiator

Perubahan suhu pada aliran berlawanan tanpa menggunakan radiator mengalami kenaikan temperature di menit ke 40 dan aliran berlawanan menggunakan mengalami penurunan pada menit 40 , dengan demikian system yang menggunakan radiator lebih efektif menurunkan temperature air dibandingkan dengan system yang tidak menggunakan radiator pada mesin heat exchanger.

\subsection{Hasil perhitungan Heat exchanger Generasi 1 dengan generasi ke 2}

Setelah didapatkan hasil pengukuran dari data penelitian generasi pertama, maka pengolahan data dapat dilakukan untuk mendapatkan perbandingan besaran laju perpindahan kalor $(Q)$, koefisien 
perpindahan panas $(h)$, penurunan tekanan $\left(\Delta P_{t}\right)$, bentuk aliran $\left(R_{e}\right)$ pada tube dengan temperature $45^{\circ} \mathrm{C}$ efisiensi $(\varepsilon)$ heat exchanger Generasi pertama dengan generasi kedua. Hasil pengolahan data dapat dilihat pada Tabel 3 di bawah.

Tabel 3. Hasil perhitungan searah dan berlawanan alat heat exchanger generasi 1

\begin{tabular}{|c|c|c|c|c|c|c|}
\hline \multirow{2}{*}{ NO } & \multirow{2}{*}{ Parameter } & \multicolumn{2}{|c|}{ Aliran searah } & \multicolumn{2}{|c|}{ Aliran berlawanan } & \multirow{2}{*}{ Satuan } \\
\hline & & Nilai $\mathrm{HE}$ & Nilai HE 2 & Nitai HE1 & Nitai HE 2 & \\
\hline 1 & LMTD & 2,05 & 6,99 & 5 & 5 & \\
\hline 2 & $\begin{array}{l}\text { Energi panas yang } \\
\text { di terima oleh } \\
\text { air dingin }\end{array}$ & 1,3677 & 4,646 & 0,4107 & 6,968 & $\mathrm{Kw}$ \\
\hline 3 & $\begin{array}{l}\text { Energi panas yang di } \\
\text { Lepas oleh fluida } \\
\text { panas }\end{array}$ & 1,0776 & 1,487 & 0,1659 & 8,264 & $\mathrm{Kw}$ \\
\hline 4 & $\begin{array}{l}\text { Tain kalor } \\
\text { Actual }\end{array}$ & 0,45136 & 4,559 & 1,0933 & 6,968 & $\mathrm{Kw}$ \\
\hline 6 & $\begin{array}{l}\text { Laju kalor } \\
\text { maksmimum }\end{array}$ & 3.66384 & 4,958 & 4,64688 & 5,206 & $w^{\circ} \mathrm{C}$ \\
\hline 7 & \begin{tabular}{|l|} 
Efeltifitas \\
Heat exchon \&!
\end{tabular} & 12 & 91,94 & 23 & 74.71 & $\%$ \\
\hline 8 & $\begin{array}{l}\text { Bilangan } \\
\text { Raynold } \\
\end{array}$ & 3780,91 & 6123 & 3004,43 & 3974 & \\
\hline
\end{tabular}

Setelah melihat tabel atas penulis menyimpulkan bahwa rata - rata perbandingan temperatur pada aliran searah air $6,99^{\circ} \mathrm{C}$, aliran berlawanan air sebesar $5^{\circ} \mathrm{C}$, aliran searah dengan radiator sebesar $2,3^{\circ} \mathrm{C}$ aliran berlawanan dengan radiator sebesar $3,3^{\circ} \mathrm{C}$.

\section{KESIMPULAN}

Berdasarkan penelitian yang dilakukan oleh peneliti, hasil dari tugas akhir dengan judul Analisa Kinerja Aliran Searah dan Berlawanan Heat Exchanger Shell and Tube berbahan tembaga dengan Temperatur $45^{\circ} \mathrm{C}$.

Maka penulis dapat mengambil kesimpulan sebagai berikut :

1. Pada dasarnya performa heat exchanger tergantung dari besarnya nilai kalor yang dilepas oleh tube dan diterima oleh shell karena tujuan dari heat exchanger atau alat penukar kalor adalah memindahkan panas dari satu fluida ke fluida lainnya yang lebih dingin.

2. Penggunaan material tembaga sebagai tube merupakan pilihan yang tepat karena tembaga merupakan konduktor panas yang baik. Tembaga memiliki titik lebur mencapai $1083^{\circ} \mathrm{C}$ sehingga sangat cocok digunakan pada tube yang dialiri fluida panas.
3. Rata - rata perbandingan temperatur pada aliran searah fluida air $6,99^{\circ} \mathrm{C}$, aliran berlawanan fluida air sebesar $5^{\circ} \mathrm{C}$, aliran searah dengan radiator sebesar $2,3^{\circ} \mathrm{C}$ aliran berlawanan dengan radiator sebesar $3,3^{\circ} \mathrm{C}$.

\section{DAFTAR PUSTAKA}

Harahap,Filipino.1982.Termodinamika Teknik Edisi Kedua.Jakarta: Penerbit Erlangga.

http://www.damaruta.com/2018/01/perpindahankalor-secara-radiasi.html, diakses dari internet pada 4 Agustus 2020 pukul 0.42

https://www.gudangpustakailmu.me/2017/02/peng ertian-panas-dan-perpindahan-panas.html, diakses dari internet pada 4 Agustus 2020 pukul 0.36

http://www.thermopedia.com/content/946/, diakses dari internet pada 4 agustus 2020 pukul 1.08

http://www.thermopedia.com/content/946/, diaksesdari internet pada 4 Agustus 2020 pukul 1.11

https://www.slideshare.net/happynezzabolongaita/ convection-current-78123949, diakses dari internet pada 4 Agustus 2020 pukul 0.38

https://www.slideshare.net/riccoriyankurniawan/pp t-perpan-shell-and-tube, diakses dari internet pada 4 Agustus 2020, pukul 0.58)

https://id.wikipedia.org/wiki/Penukar panas, diakses dari internet pada 5 Agustus 2020 pukul 13.46

Iskandar, Soetyono. 2014. Perpindahan Panas. Jakarta: Deepublish.

Koestoer.(2002). Perpindahan Kalori. Jakarta: Salemba Teknika.

Munson.(2003). Mekanika Fluida. Jakarta: PT. Gelora Aksara Pratama.

Opiyan Gutama.(2019). Analisa Efektifitas Alat Penukar Kalor Heat Exchager Modul Tabung Berbahan Tembaga Aliran Searah Dan Berlawanan Dengan Media Air Sebagai Fluida Panas Dan Dingin. Tangerang: Universitas Muhammadiyah

Q.Kern, Donald. 1965. Process Heat Transfer. New York: McGraw Hill Book. 